\title{
Determinants of survival in very low birth weight neonates in a public sector hospital in Johannesburg
}

\author{
Daynia E Ballot*1, Tobias F Chirwa² and Peter A Cooper ${ }^{1}$
}

\begin{abstract}
Background: Audit of disease and mortality patterns provides essential information for health budgeting and planning, as well as a benchmark for comparison. Neonatal mortality accounts for about $1 / 3$ of deaths $<5$ years of age and very low birth weight (VLBW) mortality for approximately $1 / 3$ of neonatal mortality. Intervention programs must be based on reliable statistics applicable to the local setting; First World data cannot be used in a Third World setting. Many neonatal units participate in the Vermont Oxford Network (VON); limited resources prevent a significant number of large neonatal units from developing countries taking part, hence data from such units is lacking. The purpose of this study was to provide reliable, recent statistics relevant to a developing African country, useful for guiding neonatal interventions in that setting.
\end{abstract}

Methods: This was a retrospective chart review of 474 VLBW infants admitted within 24 hours of birth, between 1 July 2006 and 30 June 2007, to the neonatal unit of Charlotte Maxeke Johannesburg Academic Hospital (CMJAH) in Johannesburg, South Africa. Binary outcome logistic regression on individual variables and multiple logistic regression was done to identify those factors determining survival.

Results: Overall survival was 70.5\%. Survival of infants below 1001 grams birth weight was $34.9 \%$ compared to $85.8 \%$ for those between 1001 and 1500 grams at birth. The main determinant of survival was birth weight with an adjusted survival odds ratio of 23.44 (95\% Cl: 11.22 - 49.00) for babies weighing between 1001 and 1500 grams compared to those weighing below 1001 grams. Other predictors of survival were gender (OR 3. 21; 95\% Cl 1.6 - 6.3), birth before arrival at the hospital (BBA) (OR 0.23; 95\% Cl: 0.08 - 0.69), necrotising enterocolitis (NEC) (OR 0.06; 95\% Cl: 0.02 - 0.20), hypotension (OR $0.05 ; 95 \% \mathrm{Cl} 0.01-0.21$ ) and nasal continuous positive airways pressure (NCPAP) (OR 4.58; $95 \% \mathrm{Cl} 1.58$ - 13.31).

Conclusions: Survival rates compare favourably with other developing countries, but can be improved; especially in infants < 1001 grams birth weight. Resources need to be allocated to preventing the birth of VLBW babies outside hospital, early neonatal resuscitation, provision of NCPAP and prevention of NEC.

\section{Background}

The fourth Millennium Development Goal is to reduce the mortality of children under the age of 5 years by two thirds, before the year 2015. Neonatal mortality accounts for $37 \%$ of deaths below the age of 5 years and "improved neonatal and maternal care could save the lives of countless newborns" [1]. In the Perinatal Problem Identification Program (PPIP) http://www.ppip.co.za, a self

* Correspondence: daynia.ballot@wits.ac.za

1 Department of Paediatrics, University of the Witwatersrand Medical School, York Road, Parktown, Johannesburg, South Africa

Full list of author information is available at the end of the article reporting data base that covers about $40 \%$ of births in South Africa, the early neonatal mortality rate has been static over the past few years at about 9.5 per 1000 live births [2]. However, the majority of neonatal deaths remain unaudited and the national figure is thus probably higher. Very low birth weight (VLBW) infants represent a vulnerable group of newborns with a high mortality rate. There are many reports of factors affecting early survival of VLBW infants; these are summarized in Table 1[3-22]. The survival rate of VLBW infants worldwide ranges between $43 \%$ in developing countries such as Jamaica [21] 
Table 1: Survival of Very Low Birth Weight infants

\begin{tabular}{|c|c|c|c|c|c|c|}
\hline Location & $\begin{array}{l}\text { Weight (Main } \\
\text { inclusion } \\
\text { criteria) }\end{array}$ & $\begin{array}{l}\text { Time } \\
\text { Period }\end{array}$ & $\begin{array}{l}\text { Number of } \\
\text { babies }\end{array}$ & Survival & $\begin{array}{l}\text { Factors associated with survival } \\
\text { of babies }\end{array}$ & Reference \\
\hline Texas & VLBW & $\begin{array}{l}1977 \\
1995\end{array}$ & & $\begin{array}{l}50 \% \\
81 \%\end{array}$ & $\begin{array}{l}\text { Number of babies offered } \\
\text { mechanical ventilation; Black } \\
\text { females survival advantage }\end{array}$ & [3] \\
\hline Israel & VLBW & $1985-87$ & 69 & $70 \%$ & & [4] \\
\hline Italy & $\begin{array}{l}\text { VLBW } \\
\text { ELBW }\end{array}$ & 1987-1988 & 634 & $\begin{array}{l}77 \% \\
44 \%\end{array}$ & $\begin{array}{l}\text { Lower Birth weight or } \\
\text { gestational age, Gender, No } \\
\text { antenatal steroids, } 1 \text { minute } \\
\text { Apgar, No spontaneous } \\
\text { respiration in delivery room, } \\
\text { body temperature/pH on } \\
\text { admission }\end{array}$ & [5] \\
\hline Malaysia & VLBW & 1989-1990 & 329 & $40 \%$ & $\begin{array}{l}\text { Lower birth weight/gestational } \\
\text { age }\end{array}$ & [6] \\
\hline $\begin{array}{l}\text { Netherla } \\
\text { nds }\end{array}$ & VLBW & $\begin{array}{l}1983 \\
1995\end{array}$ & $\begin{array}{l}1388 \\
2006\end{array}$ & $\begin{array}{l}75 \% \\
90 \%\end{array}$ & $\begin{array}{l}\text { Delivery in tertiary centre, } \\
\text { prolonged artificial ventilation, } \\
\text { Caesarean delivery }\end{array}$ & [7] \\
\hline Taiwan & VLBW & 1995-1998 & 162 & $78.4 \%$ & & {$[8]$} \\
\hline $\begin{array}{l}\text { South } \\
\text { America }\end{array}$ & VLBW & 1997-1998 & $\begin{array}{l}385 \\
\text { (11 neonatal } \\
\text { units) }\end{array}$ & $\begin{array}{l}73 \% \\
(49-89 \%)\end{array}$ & $\begin{array}{l}\text { Birth weight, gestational age, No } \\
\text { antenatal steroids, air leaks }\end{array}$ & [9] \\
\hline $\begin{array}{l}\text { Sofia } \\
\text { (Bulgaria) }\end{array}$ & $\begin{array}{l}\text { VLBW } \\
\text { ELBW }\end{array}$ & 1998-1999 & $\begin{array}{l}122 \\
61\end{array}$ & $\begin{array}{l}86 \% \\
54 \%\end{array}$ & $\begin{array}{l}\text { Birth weight, gestational age, } \\
\text { low Apgar scores, Cord Ph }<7.1 \text {, } \\
\text { Need for cardiac compressions/ } \\
\text { adrenaline in delivery room }\end{array}$ & {$[10]$} \\
\hline $\begin{array}{l}\text { New } \\
\text { Zealand }\end{array}$ & VLBW & $\begin{array}{l}1986 \\
1998\end{array}$ & $\begin{array}{l}413 \\
1084\end{array}$ & $\begin{array}{l}81 \% \\
90.3 \%\end{array}$ & $\begin{array}{l}\text { Delivery in tertiary centre, No } \\
\text { antenatal steroids }\end{array}$ & [11] \\
\hline Thailand & $\begin{array}{l}\text { VLBW } \\
\text { ELBW }\end{array}$ & 1996 & 613 & $\begin{array}{l}76 \% \\
49 \%\end{array}$ & $\begin{array}{l}\text { Gestational age, birth weight, } \\
\text { delivery room resuscitation, } \\
\text { Pneumothorax }\end{array}$ & [12] \\
\hline $\begin{array}{l}\text { East } \\
\text { Anglia } \\
\text { (England) }\end{array}$ & VLBW & 1993-1997 & 1244 & $75-79 \%$ & $\begin{array}{l}\text { Gestational age, Birth weight, No } \\
\text { antenatal steroids }\end{array}$ & {$[13]$} \\
\hline $\begin{array}{l}\text { USA } \\
\text { (NICHD) }\end{array}$ & VLBW & $\begin{array}{l}1995-1996 \\
1997-2002\end{array}$ & & $\begin{array}{l}84 \% \\
85 \%\end{array}$ & & [14] \\
\hline Turkey & VLBW & $1997-2002$ & 122 & $84 \%$ & Birth Weight & {$[15]$} \\
\hline Spain & VLBW & $\begin{array}{l}2002 \\
2005\end{array}$ & 8942 & $\begin{array}{l}80.6 \% \\
84.8 \%\end{array}$ & Outborn, birthweight & {$[16]$} \\
\hline
\end{tabular}


Table 1: Survival of Very Low Birth Weight infants (Continued)

\begin{tabular}{|c|c|c|c|c|c|c|}
\hline India & VLBW & $\begin{array}{l}3 \text { years } \\
\text { (not } \\
\text { stated) }\end{array}$ & 260 & $63 \%$ & $\begin{array}{l}\text { Birth weight, gestational age, } \\
\text { maternal bleed, } 1 \text { minute Apgar, } \\
\text { apnoea, neonatal septicaemia, } \\
\text { shock, hypothermia, no } \\
\text { antenatal steroids }\end{array}$ & [17] \\
\hline Brazil & VLBW & $2004 / 5$ & $\begin{array}{l}579 \\
(16 \text { tertiary } \\
\text { units) }\end{array}$ & $\begin{array}{l}84 \% \\
(69-95 \%)\end{array}$ & $\begin{array}{l}\text { Gestational age, maternal } \\
\text { hypertension, } 5 \text { minute Apgar, } \\
\text { respiratory distress, place of birth }\end{array}$ & [18] \\
\hline Malaysia & VLBW & $\begin{array}{l}1993 \\
2003\end{array}$ & $\begin{array}{l}69 \\
60\end{array}$ & $\begin{array}{l}62,3 \% \\
81,6 \%\end{array}$ & & [19] \\
\hline Thailand & $\begin{array}{l}\text { VLBW } \\
\text { ELBW }\end{array}$ & $2002 / 3$ & 78 & $\begin{array}{l}81 \% \\
52 \%\end{array}$ & $\begin{array}{l}\text { Birth weight, gestational age, } \\
\text { congenital anomalies, No } \\
\text { antenatal steroids, } 5 \text { minute } \\
\text { Apgar, intubation in delivery } \\
\text { room, respiratory distress } \\
\text { syndrome }\end{array}$ & [20] \\
\hline Jamaica & ELBW & $2002 / 3$ & 47 & $43 \%$ & $\begin{array}{l}\text { Gestational age, birth weight, } \\
\text { gender, No antenatal steroids, } \\
\text { Caesarean delivery }\end{array}$ & [21] \\
\hline $\begin{array}{l}\text { South } \\
\text { Africa }\end{array}$ & $\begin{array}{l}\text { VLBW } \\
\text { ELBW }\end{array}$ & $2000-2002$ & 2164 & $\begin{array}{l}71 \% \\
32 \%\end{array}$ & $\begin{array}{l}\text { Birth weight, } 1 \& 5 \text { minute } \\
\text { Apgars, Caesarean delivery, } \\
\text { antenatal care, gender }\end{array}$ & {$[22]$} \\
\hline
\end{tabular}

to more than $90 \%$ in developed countries, such as the Netherlands [7], with an average of about 73\% (See Table 1 ). The mortality rate for VLBW infants in Soweto, Johannesburg, between 2000 and 2002 was reported at $71 \%$ [22], which corresponds to developed countries in the mid 1980's (see Table 1).

There has been steady improvement in the overall early survival of VLBW infants over time (see Table 1) e.g. from $50 \%$ in 1977 to $81 \%$ in 1995 in Texas [3] and from $81 \%$ in 1986 to $90.3 \%$ in 1998 in New Zealand [11]. Malaysia, a developing country, showed a similar improvement from $62 \%$ in 1993 to $81.6 \%$ in 2003 [19]. The degree of improvement, however, is less marked in more recent years - the NICHD showed almost no improvement in early VLBW survival between 1995/6 (84\%) and 1997 - 2002 (85\%) [14].

Audit of neonatal care by participating in a database such as the Vermont Oxford network (VON) http:// www.vtoxford.org assists quality control provides a benchmark for comparison and opportunities for research and collaboration with other neonatal units. In developing countries with busy, under-resourced neonatal units, participation in the VON is difficult as it requires appropriate information systems and additional dedicated staff members. There is therefore a lack of current, valid statistics from such units, even though large numbers of patients are treated annually. It is essential to have this information to guide forward planning for therapeutic interventions, budgeting and staffing, with the aim of improving outcome. Local data relevant to a developing country is essential to facilitate this planning; it is not possible to transpose data from one area to another.

The purpose of this study was to review the survival to hospital discharge and morbidity of VLBW infants at Charlotte Maxeke Johannesburg Academic Hospital (CMJAH), a busy neonatal unit in a developing country.

\section{Methods}

This was a retrospective record review of all neonates with a birth weight $<1501$ grams admitted to the neonatal unit of CMJAH within 24 hours of birth from 1 July 2006 to 31 June 2007. All inborn neonates were admitted directly to a labour ward nursery, so statistics included inborn babies who died shortly after birth. VLBW babies who were delivered at outlying primary level hospitals or clinics and those who were born before arrival in hospital 
(BBA) were also admitted to the neonatal unit. Data was entered from hospital records onto a Microsoft Access (2003) database. Maternal information obtained from the delivery records included age, parity, gravidity, antenatal care, administration of antenatal steroids, syphilis screening and treatment, human immunodeficiency virus (HIV) screening and prophylaxis, place of delivery, fetal presentation and mode of delivery. HIV screening followed a protocol of voluntary counseling and testing; mothers could refuse to be tested. Prophylaxis was only given to infants where mothers were proven to be HIV positive. Polymerase chain reaction (PCR) testing to confirm HIV infection in the neonate was only done from 6 weeks of chronological age. Neonatal intensive care unit (NICU) admission was not determined by HIV exposure.

The baby's weight, Apgar scores and details of delivery room resuscitation were also obtained from the delivery records. Gestational age was determined from a combination of maternal history (expected date of delivery, height of fundus, first trimester ultrasound) and the Ballard score, which was done by attending clinical staff. The birth weight was plotted on Fenton [23] growth charts to determine whether the baby was appropriate for gestational age (AGA), small for gestational age (SGA) or large for gestational age (LGA). Information was available on all patients until hospital discharge. Neonatal records were reviewed by the primary author (DEB) and the final diagnoses assigned by the attending clinical staff were confirmed using the available clinical information and results of investigations. The neonatal information included duration of hospital stay, respiratory diagnosis (including hyaline membrane disease (HMD)), duration of oxygen therapy, pneumothorax, neonatal jaundice (NNJ), phototherapy, exchange transfusion, patent ductus arteriousus (PDA) and treatment, necrotizing enterocolitis (NEC) and management, intraventricular haemorrhage (IVH) and grade, periventricular leukomalacia (PVL), hypotension, infection and causative organism blood results, retinopathy of prematurity (ROP), bronchopulmonary dysplasia (BPD) (defined as oxygen requirement at 28 days of age), congenital anomalies, whether KMC was done and final outcome (discharge or death). IVH was graded according to Papile [24] the diagnosis of NEC was given if the baby had modified Bell's stage 2 or 3 [25]; ROP was diagnosed by an ophthalmologist; PDA was confirmed on echocardiogram by a paediatric cardiologist.

The cause of death was reviewed by the primary author (DEB) and classified according to the PPIP classification http://www.ppip.co.za. The PPIP was established in 1999 in South Africa as a national tool for perinatal death audit. In order to have manageable data, the single most likely cause of death is listed - major categories include prematurity, asphyxia, infection and congenital anomaly.
Each category is further subdivided into sub-categories; prematurity is subdivided into extreme immaturity, HMD, IVH, NEC and pulmonary haemorrhage. No postmortem examinations were done on the study patients. Details of ICU admissions include indication for ventilation, dates and type of ventilatory support, (IPPV or NCPAP) and surfactant therapy. Babies who received both NCPAP and IPPV were classified as needing ventilator assistance for the purposes of analysis.

Babies were managed according to the unit policies at the time. Ventilatory support was offered to babies above 900 grams birth weight, due to severely limited tertiary resources. Babies were not routinely intubated or given NCPAP in the delivery room; ventilatory support (including NCPAP) was commenced when the infant showed signs of respiratory failure. All babies, irrespective of birth weight, were provided with standard neonatal care (nursed in an incubator, given supplemental oxygen, intravenous fluids, antibiotic therapy, blood transfusion, phototherapy as needed and KMC). Surfactant therapy was only given as rescue therapy to babies on ventilatory support, usually to those patients who did not wean rapidly from supplementary oxygen. A second dose of surfactant could be given if the baby had responded to the initial dose and then deteriorated again. NCPAP was introduced to the neonatal unit March 2006. During the period of the study, there was no rooming in facility, so mothers could only do KMC intermittently during the day. KMC was introduced once a baby was in room air and tolerating full enteral feeds. Cranial ultrasound was done during the first week of life by a paediatric neurologist and, if indicated, repeated after 1 to 2 weeks and just prior to discharge. Babies who died within the first 72 hours may not have undergone a cranial ultrasound. Screening for retinopathy of prematurity was done by an ophthalmologist at 36 weeks post conceptional age. If babies were discharged prior to this age, an outpatient appointment was booked for the ophthalmology clinic. Babies were discharged home once they had established enteral feeds, were off supplemental oxygen, maintaining temperature and had achieved a weight of 1600 grams. Some babies were discharged to regional step down facilities for weight gain, close to the time of discharge home.

\section{Statistical analysis}

Statistical analysis was done on a personal computer using SPSS version 17 (SPSS Inc. http://www.spss.com). Continuous variables were summarised using mean and $95 \%$ confidence intervals, while categorical variables were summarised as ratios and percentages. For the purposes of analysis, babies transferred out and those discharged home directly were combined as "survivors" and compared to those babies that died during their hospital admission. Cross-tabulations of categorical variables with 
survival were produced and statistical associations between these categorical variables and survival outcome were done using the Chi-Square test of association. Normally distributed continuous variables were compared using the unpaired $t$ test and the Mann-Whitney $U$ test was used to compare discrete variables and those continuous variables that were not normally distributed. Binary outcome logistic regression was done on individual variables to predict survival. Those variables which were significant at the univariate analysis were entered into a multiple logistic regression using the backward selection procedure. All the statistical tests were conducted at 5\% significance level.

\section{Ethics}

The study was approved by the ethics committee of the University of the Witwatersrand for research on human subjects.

\section{Results}

Among the four hundred and eighty eight eligible VLBW babies who were admitted during the study period, 474 records $(97.1 \%)$ of VLBW babies born to 448 mothers were retrieved and available for review.

The overall survival was 334/474 (70.5\%). The mean birth weight was 1133.5 grams (95\% CI 1111.9 - 1155.0$)$, mean gestational age was 29.9 weeks (95\% CI 29.6 - 30.1) and mean duration of hospitalisation was 25.8 days $(95 \%$ CI 23.8 - 27.8). The mean age at time of death was 5.77 days (95\% CI 3.66 - 7.88) and of discharge/transfer was 34.23 days ( $95 \%$ CI 32.13 - 36.32). The mean duration of supplemental oxygen was 8.2 days (95\% CI 6.8 - 9.7) and mean duration of mechanical ventilation was 8.08 days (95\% CI 6.15 - 10.01).

\section{Birth weight and gestational age}

The mean birth weight of survivors (1213 grams; 95\% CI: 1192.5 - 1234.1) was significantly greater $(\mathrm{p}<0.001)$ than that for babies that died (942.5 grams; $95 \%$ CI: 904.5 980.5). The mean gestation period for survivors (30.7 weeks, 95\% CI: 30.4 - 31.0) was significantly more advanced than that of those who died (27.6 weeks, 95\% CI: 27.2 - 28.1). The median 5 minute Apgar score of those babies that survived, 8 (IQR: 1-9) was significantly higher than the non survivors, 6 (IQR: 1-10) with $\mathrm{p}=$ 0.005 . Mortality by birth weight category is shown in figure 1. As survival seem to increase with birth weight, an association between a quadratic term was fitted which also showed significant association $(\mathrm{p}=0.010)$ with survival.

Survival was closely related to birth weight category ranging from zero below 601 grams to $62 \%(32 / 52)$ from 901 to 1000 grams and 93\% (67/72) from 1301 to 1500 grams. The survival of extremely low birth weight infants (< 1001 grams) was $34.9 \%$ (50/143) compared to $85.8 \%$ (284/331) for babies with a birth weight from 1001 to 1500 grams. The adjusted survival odds ratio was 23.44 (95\% CI: 11.22 - 49.00) for babies weighing from 1001 to 1500 grams compared to those weighing below 1001 grams.

The main cause of death according to the PIPP classification is shown in Table 2. The single most common cause of death was extreme multi-organ immaturity, in $40 \%$ of cases, followed by HMD in $15 \%$ of cases.

\section{Maternal and delivery period}

The mean maternal age was 26.5 years (95\% CI: 25.8 $27.1)$ and $37.3 \%(152 / 407)$ were primiparous. Risk factors for mortality related to antenatal care, labour and delivery are presented in Table 3. Emergency Caesarean section (CS) was done for fetal distress in 63/229 (27.5\%) of cases. Where emergency CS was done for maternal indications, the most common reasons were pregnancy induced hypertension $45.6 \%$ (63/138) followed by ante partum haemorrhage in $13 \%$ (18/138). No CS was done for HIV infection alone.

Odds ratios with 95\% confidence intervals are presented for each risk factor. Significant predictors of survival on univariate analysis were size for gestational age, gender, antenatal care, place of delivery, mode of delivery, the need for delivery room resuscitation and hypothermia at birth. Maternal HIV exposure, maternal infection with syphilis, the administration of antenatal steroids and the presenting part at delivery did not predict survival. Only $69 \%$ of mothers had known HIV status and $36.5 \%$ of mothers had received antenatal steroids.

\section{Neonatal period}

Air leak was recorded in 3 patients $(0.6 \%)$ and high frequency ventilation was used in 3 patients $(0.6 \%)$. These

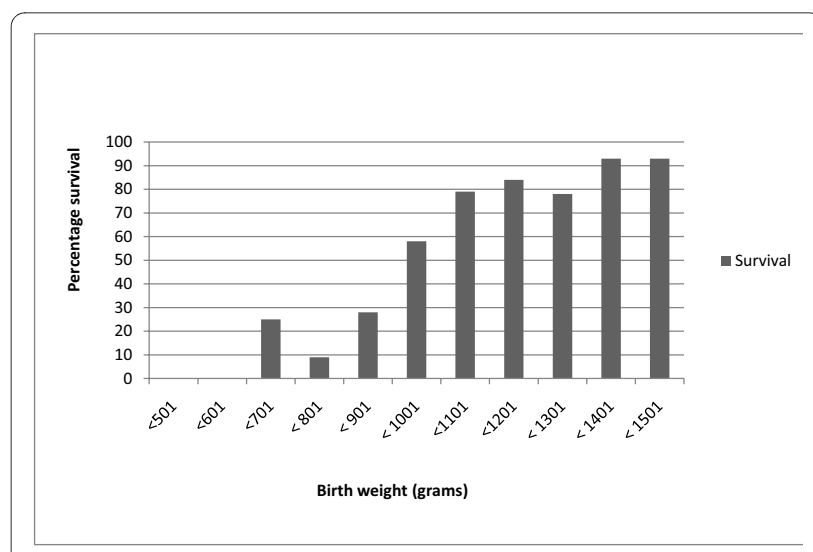

Figure 1 Survival by birthweight category 
Table 2: PPIP classification of mortality

\begin{tabular}{lcc}
\hline Cause of death & Cases & $\%$ \\
\hline Extreme mulitorgan immaturity & 56 & 40 \\
HMD & 22 & 15.7 \\
Asphyxia & 17 & 12.1 \\
NEC & 14 & 10 \\
Nosocomial sepsis & 14 & 10 \\
Septicaemia & 3 & 2.1 \\
Congenital infection & 2 & 1.4 \\
IVH & 3 & 2.1 \\
Congenital abnormality & 4 & 2.8 \\
Pulmonary Haemorrhage & 2 \\
Unspecified & 3 \\
\hline
\end{tabular}

variables were not included in the analysis due to small numbers. Bronchopulmonary dysplasia (BPD) (defined as oxygen requirement $>28$ days) was present in $42(8.8 \%)$ of babies. Nevirapine prophylaxis was given to $97 / 120$ (80.8\%) of the HIV exposed infants; $25 / 354$ (7\%) of mothers offered HIV testing refused consent. 11/474 (2.3\%) of the babies were put up for adoption. Only $87(18.3 \%)$ of the babies were screened for ROP prior to discharge-only two babies had ROP, both of which were stage 1. KMC was done by $211 / 474$ (44.5\%) of mothers.

Odds ratios and 95\% confidence intervals for each risk factor related to the neonatal period (both disease and treatment) are shown in Table 4. HMD, NCPAP, surfactant therapy, hypotension, NEC and IVH were all predictive of survival. The need for mechanical ventilation, PDA and the presence of sepsis did not predict survival.

\section{Multivariate analysis}

Multivariate logistic regression is shown in Table 5 for complete cases i.e. a complete case analysis with the entered variables defining a complete case. Variables entered into the model included birth weight, SGA, gender, antenatal care, place of birth, mode of delivery, NEC grade $2 / 3$, hypotension, $\mathrm{HMD}$, resuscitation at birth, hypothermia, surfactant therapy and NCPAP. Gestational age was not included in the model as it is highly correlated with birth weight (correlation coefficient $0.717 \mathrm{p}<$ 0.001 ) and birth weight is more accurate in our setting than estimation of gestational age. IVH was not included due to the large number of missing variables. The final model showed that birth weight, gender, resuscitation at birth, BBA, hypotension, definite NEC and provision of NCPAP were significant predictors of mortality in this population. The model predicted mortality correctly in $87 \%$ of cases. Birth weight was the single most important predictor of mortality, correctly predicting mortality in
$82.9 \%$ of cases. The odds ratio for death for birth weight $\leq$ 1001 grams was 10.41 (95\% CI 6.62 to 16.6$)$ and for gestational age $<28$ weeks was 11.97 (95\% CI 7.1 - 20.1).

\section{Discussion}

This retrospective review provides current survival rates and indicates where resources should be channeled in order to improve survival of VLBW infants in South Africa. The overall survival rate was $70.5 \%$ for VLBW infants at CMJAH 2006/2007. This is almost exactly the same as that reported from $\mathrm{CH}$ Baragwanath for 2000 2002 (71\%), [22] which reflects the similarity in practice and disease profile between the two units, which form part of a single academic complex. This survival rate also compares favorably with the global average of $73 \%$ (see Table 1), but is substantially below that of developed countries $[7,10,11,13,14,16]$. The survival of ELBW infants in the present review of $35 \%$ was less than that in other developing countries, such as Jamaica [21] and Thailand [20] but once again very similar to that of $\mathrm{CH}$ Baragwanath (32\%) [22]. The most significant cause of death in this study was extremely low birth weight/ extreme multi-organ immaturity. This is in close agreement with national data for South Africa from the same time period $-46 \%$ of all neonatal deaths were immaturity related, of which $44.9 \%$ were due to extreme immaturity and $35.6 \%$ due to HMD [26].

The main determinants of survival in the present study - birth weight, gender, being born before arrival in the hospital, resuscitation at birth, NEC, hypotension and NCPAP are not surprising and very similar to other reports on VLBW outcome [5-7,9-22]. However, the study shows that, despite great improvements in neonatal care, the VLBW survival in South Africa is below that in other developing countries $[8,9,12,15,18,20]$ and can improve substantially. This can be achieved by simple 
Table 3: Obstetric related risk factors and prediction of mortality

\begin{tabular}{|c|c|c|c|c|c|c|c|}
\hline $\begin{array}{l}\text { Variable (Valid } \\
\text { cases) }\end{array}$ & & $\begin{array}{l}\text { Category } \\
\text { total }\end{array}$ & $\begin{array}{l}\text { Survived } \\
(\%)\end{array}$ & Died (\%) & P value & Odds ratio & $\begin{array}{l}95 \% \mathrm{Cl} \text { of } \\
\text { OR }\end{array}$ \\
\hline \multirow[t]{2}{*}{ SGA (461) } & Yes & 178 & $143(80)$ & $35(20)$ & 0.001 & 2.07 & $1.32-3.22$ \\
\hline & No & 283 & $188(66)$ & $95(34)$ & & & \\
\hline \multirow[t]{2}{*}{ Gender (470) } & Female & 251 & $192(76.5)$ & $59(23.5)$ & 0.004 & 1.8 & $1.24-2.69$ \\
\hline & Male & 219 & $141(64.4)$ & $78(35.6)$ & & & \\
\hline \multirow{2}{*}{$\begin{array}{l}\text { Antenatal care } \\
\text { (474) }\end{array}$} & Yes & 256 & $197(77)$ & $59(23)$ & 0.001 & 1.97 & $1.32-2.95$ \\
\hline & No & 218 & $137(63)$ & $81(37)$ & & & \\
\hline \multirow{2}{*}{$\begin{array}{l}\text { Antenatal } \\
\text { corticosteroids } \\
(474)\end{array}$} & Given & 173 & $131(75.4)$ & $42(24.3)$ & 0.057 & 1.51 & $0.99-2.30$ \\
\hline & Not given & 301 & $203(67.4)$ & $98(32.6)$ & & & \\
\hline \multirow{2}{*}{$\begin{array}{l}\text { HIV exposed } \\
(328)\end{array}$} & Yes & 120 & $84(70)$ & $36(30)$ & 0.057 & 0.61 & $0.36-1.02$ \\
\hline & No & 208 & $165(80)$ & $43(21)$ & & & \\
\hline \multirow{2}{*}{$\begin{array}{l}\text { Syphilis } \\
\text { Exposed (474) }\end{array}$} & Yes & 12 & $7(58.4)$ & $5(42)$ & 0.351 & 0.58 & $0.18-1.85$ \\
\hline & No & 462 & $327(71)$ & $135(29)$ & & & \\
\hline \multirow{4}{*}{$\begin{array}{l}\text { Place of birth } \\
(470)\end{array}$} & & & & & $<0.001$ & & \\
\hline & Inborn & 383 & $286(74.7)$ & $97(25.3)$ & & 1 & \\
\hline & BBA & 51 & $20(39)$ & $31(61)$ & & 0.22 & $0.12-0.40$ \\
\hline & Out born & 36 & $24(66)$ & $12(33)$ & & 0.68 & $0.33-1.41$ \\
\hline \multirow{5}{*}{$\begin{array}{l}\text { Mode of } \\
\text { delivery (464) }\end{array}$} & & & & & $<0.001$ & & \\
\hline & NVD & 197 & $123(62.4)$ & $74(37.6)$ & & 1 & \\
\hline & $\begin{array}{l}\text { Vaginal } \\
\text { Breech }\end{array}$ & 25 & $13(52)$ & $12(48)$ & & 0.65 & $0.28-1.50$ \\
\hline & Elective CS & 12 & $9(75)$ & $3(25)$ & & 1.80 & $0.47-6.88$ \\
\hline & $\begin{array}{l}\text { Emergency } \\
\text { CS }\end{array}$ & 229 & $182(79.5)$ & $47(20.5)$ & & 2.33 & $1.51-3.59$ \\
\hline \multirow{2}{*}{$\begin{array}{l}\text { Presentation } \\
\text { (448) }\end{array}$} & Vertex & 401 & $290(72.3)$ & $111(27.7)$ & 0.541 & 0.82 & $0.43-1.57$ \\
\hline & Breech & 47 & $32(68.11)$ & $15(31.9)$ & & & \\
\hline \multirow{2}{*}{$\begin{array}{l}\text { Resuscitation } \\
\text { at birth (474) }\end{array}$} & Yes & 154 & $91(59.1)$ & $63(40.9)$ & $<0.001$ & 0.46 & $0.30-0.69$ \\
\hline & No & 320 & $243(75.9)$ & $77(24.1)$ & & & \\
\hline \multirow{2}{*}{$\begin{array}{l}\text { Hypothermia } \\
\text { at birth (474) }\end{array}$} & Yes & 13 & $5(38.5)$ & $8(61.5)$ & 0.01 & 0.25 & $0.08-0.78$ \\
\hline & No & 461 & $329(71.4)$ & $132(28.6)$ & & & \\
\hline \multirow{2}{*}{$\begin{array}{l}5 \text { minute } \\
\text { APGAR Score } \\
(409)\end{array}$} & Score $>=6$ & 304 & $231(76)$ & $73(24)$ & 0.093 & 1.52 & $0.93-2.46$ \\
\hline & Score $<6$ & 105 & 71 (67.6) & $34(32.4)$ & & & \\
\hline
\end{tabular}

Note: Valid cases = those with no missing data, thus, a complete case analysis

Percentages are reported for rows 
Table 4: Risk factors for mortality related to disease/treatment in the neonatal period

\begin{tabular}{|c|c|c|c|c|c|c|c|}
\hline $\begin{array}{l}\text { Risk factor (Valid } \\
\text { cases) }\end{array}$ & & Total & $\begin{array}{l}\text { Survived } \\
(\%)\end{array}$ & Died (\%) & P Value & Odds ratio & $\begin{array}{l}95 \% \mathrm{Cl} \text { of } \\
\text { Odds Ratio }\end{array}$ \\
\hline \multirow[t]{2}{*}{ HMD (437) } & Yes & 299 & $190(63.5)$ & $109(36.5)$ & $<0.001$ & 0.33 & $0.20-0.55$ \\
\hline & No & 138 & $116(84.1)$ & $22(15.9)$ & & & \\
\hline \multirow{2}{*}{$\begin{array}{l}\text { Mechanical } \\
\text { ventilation (474) }\end{array}$} & Yes & 99 & $71(71.7)$ & $28(28.3)$ & 0.76 & 1.08 & $0.66-1.76$ \\
\hline & No & 375 & $263(70.1)$ & $112(29.9)$ & & & \\
\hline \multirow[t]{2}{*}{ Nasal CPAP (474) } & Yes & 96 & $80(83.3)$ & $16(16.7)$ & 0.002 & 2.44 & $1.37-4.35$ \\
\hline & No & 378 & $254(67.2)$ & $124(32.8)$ & & & \\
\hline \multirow{2}{*}{$\begin{array}{l}\text { Surfactant } \\
\text { therapy (474) }\end{array}$} & Yes & 90 & $73(81)$ & $17(19)$ & 0.014 & 2.02 & $1.15-3.58$ \\
\hline & No & 384 & $261(68)$ & $123(32)$ & & & \\
\hline \multirow[t]{2}{*}{ Sepsis (445) } & Yes & 62 & $40(64.5)$ & $22(35.5)$ & 0.085 & 0.61 & $0.34-1.08$ \\
\hline & No & 383 & $287(74.9)$ & $96(25.1)$ & & & \\
\hline \multirow{2}{*}{$\begin{array}{l}\text { Gram Negative } \\
\text { (474) }\end{array}$} & Yes & 37 & $21(56.8)$ & $16(43.2)$ & 0.057 & 0.52 & $0.26-1.03$ \\
\hline & No & 437 & $313(71.6)$ & $124(28.4)$ & & & \\
\hline \multirow{2}{*}{$\begin{array}{l}\text { Gram Positive } \\
\text { (474) }\end{array}$} & Yes & 28 & $23(82.1)$ & $5(17.9)$ & 0.163 & 1.99 & $0.74-5.36$ \\
\hline & No & 446 & $311(69.7)$ & $135(30.3)$ & & & \\
\hline \multirow[t]{2}{*}{ PDA (474) } & Yes & 26 & $18(69)$ & $8(31)$ & 0.887 & 0.94 & $0.4-2.21$ \\
\hline & No & 448 & $316(71)$ & $132(29)$ & & & \\
\hline \multirow{2}{*}{$\begin{array}{l}\text { Hypotension } \\
(\mathbf{4 7 4 )}\end{array}$} & Yes & 23 & $7(30)$ & $16(70)$ & $<0.001$ & 0.166 & $0.07-0.41$ \\
\hline & No & 451 & $327(73)$ & $124(27)$ & & & \\
\hline \multirow{2}{*}{$\begin{array}{l}\text { NEC grade } 2 / 3 \\
(474)\end{array}$} & Yes & 26 & $9(35)$ & $17(65)$ & $<0.001$ & 0.2 & $0.09-0.46$ \\
\hline & No & 448 & $325(73)$ & $123(27)$ & & & \\
\hline \multirow[t]{7}{*}{ IVH (328) } & & & & & 0.004 & & \\
\hline & No & 253 & $209(83)$ & $44(17)$ & & 1 & \\
\hline & Gr 1 & 11 & $8(72.7)$ & $3(27.3)$ & & 0.56 & $0.14-2.20$ \\
\hline & Gr 2 & 40 & $25(62.5)$ & $15(37.5)$ & & 0.35 & $0.17-0.72$ \\
\hline & Gr 3 & 16 & $12(75)$ & $4(25)$ & & 0.63 & $0.19-2.05$ \\
\hline & Gr 4 & 4 & $1(25)$ & $3(75)$ & & 0.07 & $0.01-0.69$ \\
\hline & PVL & 4 & $2(50)$ & $2(50)$ & & 0.21 & $0.03-1.53$ \\
\hline
\end{tabular}

Note: Valid cases $=$ those with no missing data

Percentages are reported for rows

interventions such as ensuring preterm infants are delivered in hospital, improved neonatal resuscitation and provision of NCPAP. A provincial neonatal resuscitation programme has recently been introduced to improve the resuscitation skill of birth attendants. Patient education as to when to seek help during labour and improved emergency transport will be required to prevent preterm infant BBA. Although provision of antenatal steroids did not achieve statistical significance in this study, the num- ber of women receiving antenatal steroids is unacceptably low (36\%). This is a specific obstetric intervention that needs to be addressed and will improve neonatal outcome. Delivery by CS was advantageous, but may reflect those patients who have received antenatal care, including antenatal steroids and who delivered in hospital. It is not feasible to do elective CS on all preterm deliveries in our resource constrained setting. 
Table 5: Multivariate logistic regression analysis with adjusted estimates of Odds Ratio (95\% $\mathrm{Cl})$.

\begin{tabular}{|c|c|c|c|}
\hline Variable & Odds Ratio & 95\% Confidence Interval & P-Value \\
\hline Birth Weight & 1.008 & $1.006-1.01$ & $<0.001$ \\
\hline \multicolumn{4}{|l|}{ Gender } \\
\hline Male & 1.00 & & \\
\hline Female & 3.21 & $1.6-6.31$ & 0.001 \\
\hline \multicolumn{4}{|l|}{ Place of Birth } \\
\hline Inborn & 1.00 & & \\
\hline BBA & 0.23 & $0.08-0.69$ & 0.008 \\
\hline Out born & 0.35 & $0.10-1.20$ & 0.096 \\
\hline \multicolumn{4}{|l|}{ Resuscitation } \\
\hline No & 1.00 & & \\
\hline Yes & 0.47 & $0.24-0.92$ & 0.029 \\
\hline \multicolumn{4}{|l|}{ Nasal CPAP } \\
\hline No & 1.00 & & \\
\hline Yes & 4.58 & $1.58-13.31$ & 0.005 \\
\hline \multicolumn{4}{|l|}{ Hypotension } \\
\hline No & 1.00 & & \\
\hline Yes & 0.05 & $0.01-0.21$ & $<0.001$ \\
\hline \multicolumn{4}{|c|}{ NEC Grade 2/3 } \\
\hline No & 1.00 & & \\
\hline Yes & 0.06 & $0.02-0.20$ & $<0.001$ \\
\hline
\end{tabular}

South Africa is a developing country with limited health resources and high patient numbers; it is not possible to provide full tertiary support to every VLBW infant. For many years this problem has been addressed by limiting ventilatory support, including the administration of surfactant and NCPAP, to those neonates above a specified birth weight cut off. Prior to the widespread use of NCPAP, this cut off was 1000 grams. The ventilation cut off was reduced to 900 grams just before the study period, with the introduction of NCPAP to the unit. The poor survival or our ELBW infants is undoubtedly influenced by this policy and NCPAP with surfactant should be provided to babies from 750 grams in order to bring our ELBW survival rate up to that in other developing countries [12,20,21].

NEC and hypotension were the other significant predictors of mortality. The overall rate of NEC was 5.5\%, which accounted for $10 \%$ of the deaths. Interestingly the rate of NEC was comparable to that in the VON in 2005, which represents well resourced settings. Prevention of NEC should also be a priority, including promotion of breastfeeding. Our rate of breastfeeding at the time of the study was extremely low, mainly due to the HIV epidemic. Only $69 \%$ of mothers were tested for HIV, but $36 \%$ were positive. The protocol during the study period was to formula feed HIV exposed babies. Of concern, is the high rate of untested mothers, the relatively high rate of refusal to be tested and failure to administer HIV prophylaxis in $16.4 \%$ of exposed mothers; this may reflect the mothers who were diagnosed after the early neonatal period. Ensuring that all mothers are counseled and tested for HIV is essential to prevent mother to child transmission and, in turn, facilitate the promotion of breastfeeding and reduction of NEC. Although 36\% of screened mothers were HIV positive, HIV status did not predict neonatal outcome. This is in agreement with a study from Durban [27] which found that HIV exposed babies were not different from HIV unexposed neonates with regard to birth weight, gestational age, need for ICU admission, complications of ventilation, sepsis, IVH or death. Furthermore, most HIV exposed neonates are subsequently uninfected. HIV exposure is not a major determinant of neonatal survival and is not used as a criterion for ICU admission.

CMJAH represents a high risk obstetric population with many referrals for obstetric complications, the most frequent of which is pregnancy induced hypertension. Improved management of this obstetric complication may reduce the number of VLBW infants. There are also significant social problems with $2.6 \%$ of the babies deliv- 
ered as a result of illegal termination of pregnancy and $2.3 \%$ being given up for adoption. The whole issue of preventing unwanted pregnancy is also pertinent in our population.

The low rate of in hospital screening for ROP is also an area of concern and needs to be improved. A significant number of babies are referred to the ophthalmologist at the time of their first follow up visit for ROP screening, but this may be too late in terms of adequate intervention.

\section{Conclusion}

Although the overall survival of VLBW infants in our unit compares with the global average (see Table 1), the survival of our ELBW infants can be significantly improved. NCPAP and surfactant should be provided to ELBW infants > 750 grams birth weight. Prevention of VLBW deliveries outside the hospital, improved administration of antenatal steroids, universal screening for HIV, improved neonatal resuscitation and strategies to prevent NEC, will also improve the VLBW survival rate.

\section{Limitations of the study}

The biggest limitation of this study is the retrospective design- this is inevitably complicated by incomplete data, lost records and diagnoses provided by different caregivers. Unfortunately, the ideal prospective collection of data by designated study personnel is extremely difficult in a developing country with limited resources (both money and manpower) where the emphasis is on service delivery.

\footnotetext{
Abbreviations

AGA: appropriate for gestational age; BBA: born before arrival at the hospital; BPD: bronchopulmonary dysplasia; $\mathrm{CH}$ : Chris Hani; CMJAH: Charlotte Maxeke Johannesburg Academic Hospital; CS: Caesarean section; ELBW: extremely low birth weight infants (< 1001 grams); HIV: human immunodeficiency virus; HMD: hyaline membrane disease; IPPV: intermittent positive pressure ventilation; ICU: intensive care unit; IVH: intraventricular haemorrhage; LGA: large for gestational age; NEC: necrotising enterocolitis; NIHCD: National Institute of child health and development; NCPAP: nasal continuous positive airways pressure; PDA: patent ductus arteriousus; PVL: periventricular leukomalacia; ROP. retinopathy of prematurity; SGA: small for gestational age; VLBW: very low birth weight; VON: Vermont Oxford Network.
}

\section{Competing interests}

The authors declare that they have no competing interests.

\section{Authors' contributions}

Data collection and manuscript preparation was done by DEB; statistical analysis was done by DEB and TFC while PAC was involved in manuscript preparation. The final manuscript was approved by all authors.

\section{Acknowledgements}

We wish to acknowledge and thank Dr Cheryl Mackay, for her review and comments on the manuscript and Prof Jacky Galpin for initial assistance with the statistical analysis. The statistical analysis was partly funded from a grant from the Medical Research Council of South Africa.

\section{Author Details}

1 Department of Paediatrics, University of the Witwatersrand Medical School, York Road, Parktown, Johannesburg, South Africa and 2Epidemiology and Biostatistics Division, School of Public Health, University of the Witwatersrand Medical School, York Road, Parktown, Johannesburg, South Africa

Received: 17 December 2009 Accepted: 6 May 2010

Published: 6 May 2010

\section{References}

1. United Nations: Reduce Child Mortality. The Millennium Development Goals Report New York 2008:21-3.

2. Patrick ME: Neonatal deaths: Do they count? In Saving Children 2006: A survey of child healthcare in South Africa Edited by: Stephen CRPM. Pretoria: University of Pretoria, MRC, CDC; 2008:81-5.

3. Kaiser JR, Tilford JM, Simpson PM, Salhab WA, Rosenfeld CR: Hospital survival of very-low-birth-weight neonates from 1977 to 2000 . J Perinatol 2004, 24:343-50.

4. Litt R, Seidman DS, Gross-Tsur V, Dollberg S, Gale R: A 2-year prospective study of very low birth weight infants. Isr J Med Sci 1992, 28:783-8.

5. de Vonderweid U, Carta A, Chiandotto V, Chiappe F, Chiappe S, Colarizi P, et al.: Italian Multicenter Study on Very Low Birth Weight Babies. Ann IST Super Sanita 1991, 27:633-50.

6. Boo NY: Outcome of very low birth weight neonates in a developing country: experience from a large Malaysian maternity hospital. Singapore Med J 1992, 33:33-7.

7. Anthony S, Ouden L, Brand R, Verloove-Vanhorick P, Gravenhorst JB: Changes in perinatal care and survival in very preterm and extremely preterm infants in The Netherlands between 1983 and 1995. Eur J Obstet Gynecol Reprod Biol 2004, 112:170-7.

8. Chang SC, Lin CH, Lin YJ, Yeh TF: Mortality, morbidity, length and cost of hospitalization in very-low-birth-weight infants in the era of National Health Insurance in Taiwan: a medical center's experience. Acta Paediatr Taiwan 2000, 41:308-12.

9. Grupo Colaborativo Neocosur: Very-low-birth-weight infant outcomes in 11 South American NICUs. J Perinatol 2002, 22:2-7.

10. Vakrilova L, Kalaidzhieva M, Sluncheva B, Popivanova A, Metodieva V Garnizov T: [Resuscitation in very low birth weight and extremely low birth weight newborns in the delivery room]. Akush Ginekol (Sofiia) 2002, 41:18-23.

11. Darlow BA, Cust AE, Donoghue DA: Improved outcomes for very low birth weight infants: evidence from New Zealand national population based data. Arch Dis Child Fetal Neonatal Ed 2003, 88:F23-F28.

12. Tsou Kl, Tsao PN: The morbidity and survival of very-low-birth-weight infants in Taiwan. Acta Paediatr Taiwan 2003, 44:349-55.

13. Dorling J, D'Amore A, Salt A, Seward A, Kaptoge S, Halliday S, et al.: Data collection from very low birth weight infants in a geographical region: methods, costs, and trends in mortality, admission rates, and resource utilisation over a five-year period. Early Hum Dev 2006, 82:117-24.

14. Fanaroff AA, Stoll BJ, Wright LL, Carlo WA, Ehrenkranz RA, Stark AR, et al.: Trends in neonatal morbidity and mortality for very low birth weight infants. Am J Obstet Gynecol 2007, 196:147-8.

15. Atasay B, Gunlemez A, Unal S, Arsan S: Outcomes of very low birth weight infants in a newborn tertiary center in Turkey, 1997-2000. Tur J Pediatra 2003, 45:283-9.

16. Moro M, Figueras-Aloy J, Fernandez C, Domenech E, Jimenez R, PerezRodriguez J, et al.: Mortality for newborns of birth weight less than 1500 $\mathrm{g}$ in Spanish neonatal units (2002-2005). Am J Perinatol 2007, 24:593-601.

17. Basu S, Rathore P, Bhatia BD: Predictors of mortality in very low birth weight neonates in India. Singapore Med J 2008, 49:556-60.

18. de Almeida MF, Guinsburg R, Martinez FE, Procianoy RS, Leone CR, Marba ST, et al.: Perinatal factors associated with early deaths of preterm infants born in Brazilian Network on Neonatal Research centers. J Pediatr (Rio J) 2008, 84:300-7.

19. Ho JJ, Chang AS: Changes in the process of care and outcome over a 10 year period in a neonatal nursery in a developing country. $J$ Trop Pediatr 2007, 53:232-7 
20. Sritipsukho S, Suarod T, Sritipsukho P: Survival and outcome of very low birth weight infants born in a university hospital with level II NICU. J Med Assoc Thai 2007, 90:1323-9.

21. Trotman $\mathrm{H}$, Bell Y: Neonatal sepsis in very low birth weight infants at the University Hospital of the West Indies. West Indian Med J 2006, 55:165-9.

22. Velaphi SC, Mokhachane M, Mphahlele RM, Beckh-Arnold E, Kuwanda ML, Cooper PA: Survival of very-low-birth-weight infants according to birth weight and gestational age in a public hospital. S Afr Med J 2005, 95:504-9.

23. Fenton TR: A new growth chart for preterm babies: Babson and Benda's chart updated with recent data and a new format. BMC Pediatr 2003, 3:13.

24. Papile LA, Burstein J, Burstein R, Koffler $\mathrm{H}$ : Incidence and evolution of subependymal and intraventricular hemorrhage: a study of infants with birth weights less than 1,500 gm. J Pediatr 1978, 92:529-534.

25. Bell MJ, Ternberg JL, Feigin RD, Keating JP, Marshall R, Barton L, et al.: Neonatal necrotizing enterocolitis: therapeutic decisions based upon clinical staging. Ann Surg 1978, 187:1-7.

26. Saving babies $2006-2007$ : Sixth perinatal care survey of South Africa. Edited by: Pattinson RC. Tshepesa Press, Pretoria; 2009.

27. Adhikhari M, Jeena P, Pillay T, Moodley A, Kiepiela P, Cassol S: The HIV-1 exposed neonate: Outcome of intensive care management in the first week of life. Indian Paediatrics 2005, 42:1215-1219.

\section{Pre-publication history}

The pre-publication history for this paper can be accessed here: http://www.biomedcentral.com/1471-2431/10/30/prepub and take full advantage of:

- Convenient online submission

- Thorough peer review

- No space constraints or color figure charges

- Immediate publication on acceptance

- Inclusion in PubMed, CAS, Scopus and Google Scholar

- Research which is freely available for redistribution 